\title{
Psychological distress and its associated risk factors among university students
}

\author{
(iD) Tingting $L i^{1}$ \\ (iD) Xu Zhang ${ }^{1}$ \\ DMingming Chen ${ }^{1}$ \\ (D) Rui Wang ${ }^{2}$ \\ (D) Lianping $\mathrm{He}^{1}$ \\ (D)Baohong Xue \\ (iD) Dexun Zhao'
}

1. Department, College of experience industry, Anhui polytechnic university, Wuhu, Anhui 241000 , China. 2. Training canter for comprehensive quality and ability of college students, Anhui institute of information technology, Wuhu, Anhui 241003, China.

http://dx.doi.org/10.1590/1806-9282.66.4.414

\section{SUMMARY}

OBJECTIVE: Psychological distress is an important mental health problem among university students. The goal of this study was to determine psychological distress and its associated risk factors among students in the Anhui province.

METHODS: A cross-sectional study was conducted in a sample of 1304 students. In this study, a self-administered questionnaire consisting of the general demography and General Health Questionnaire (GHQ-12) was completed. Psychological distress was assessed using the GHQ-12-item questionnaire. A dichotomous category split was imposed on the GHQ-12 for the purpose of analysis. A GHQ-12 score of 4 or higher indicated psychological distress. The data were analyzed by SPSS 20.0 system.

RESULTS: A total of 1304 samples were analyzed in this study. The results indicated that the education level of the father and mother was associated with the students' psychological distress ( $P<0.001)$. A significant association was found between high-intensity exercise and low-intensity exercise and psychological distress. However, no significant difference was identified between gender and psychological distress $(P=0.173)$.

CONCLUSION: The education level of parents, high-intensity exercise, and low-intensity exercise were associated with psychological distress. Our results suggest that it is indispensable to raise awareness of psychological disorders and its associated risk factors among university students. Further studies are required to develop appropriate interventions for high-risk groups.

KEYWORDS: Stress, psychological. Risk factors. Students. Universities.

\section{INTRODUCTION}

Psychological distress is common worldwide ${ }^{1,2}$. The characteristics of psychological distress include lack of enthusiasm, desperation about the future, and symptoms of anxiety ${ }^{3}$. The prevalence of psychological distress varies with country. About $50 \%$ of university students in Italy suffer from psychological distress ${ }^{4}$, about $40 \%$ in the $\mathrm{UK}^{5}$, and $50 \%$ in
Spain ${ }^{5}$. It is predicted that a quarter of the global population will be affected by depressive symptoms at some stage in their life. More than 1/3 of undergraduates suffer from some type of dysfunction due to psychological distress, and nearly $1 / 10$ students have considered attempting suicide, according to the American National College Health Assessment ${ }^{6}$.

DATE OF SUBMISSION: 01-Sep-2019

DATE OF ACCEPTANCE: 12-Nov-2019

CORRESPONDING AUTHOR: Dexun Zhao

College of experience industry, Anhui polytechnic university, Wuhu, Anhui, China - 241000

Tel/Fax: +86 553-2871231

E-mail: baohongxue@yeah.net 
Psychological distress has become an important public health problem.

Psychological distress among undergraduates was associated with a variety of factors across various domains such as economics, social communication, academic pressure, and coping skills. The rapid development of higher education and high expectations has brought great pressure to students ${ }^{7,8}$. However, discussions about psychological distress are limited and mostly conducted in Western societies?.

Psychological distress and its related factors vary across the globe. It is more prevalent among females than males10, and family support has been inextricably linked with it ${ }^{11}$. However, there are few studies on the mental health of Chinese college students ${ }^{12}$.

Psychological distress is an important mental health problem among university students ${ }^{9}$. The objective of this study was to determine the risk factors of psychological distress. The results indicated that the education level of parents, low- and high-intensity exercise were associated with psychological stress.

\section{METHODS}

\section{Samples}

The presented study was conducted with a cross-sectional design. A self-reported questionnaire was completed by 1310 university students. Written informed consent was obtained from all subjects.

\section{Measurement instruments}

The general demographic questionnaire, General Health Questionnaire (GHQ) scale, low-intensity and high-intensity exercise were used to measure the mental health of students in this study. The demographic characteristics of respondents mainly included gender, age, education level of the father and mother, location, household income, and exercise. GHQ was used to measure mental health ${ }^{13}$, the Likert four scale ${ }^{14}$ was adopted to calculate the score of GHQ. This scale consisted of 12 items, and the score of each item ranged from 1 to 4 . The total score of the GHQ-12 was the sum of the score of each item. A total GHQ-12 score of 4 or above was defined as psychological distress.

Low-intensity exercise was defined as at least 20 minutes or more of sports such as walking or shadowbox. In terms of low-intensity exercise frequency, $\mathrm{n}=232$ (17.8\%) “never exercised”, while n=718 (55.1\%) exercised "1 to 2 times per week", n=270 (20.7\%) exercised “ 3 to 4 times per week", and n=84 (6.4\%) “More than 5 times per week". High-intensity exercise was defined as at least 20 minutes or more of sports such as playing ball or running.

\section{Statistical analysis}

Statistical analyses were performed using SPSS 20.0 (Inc. Chicago, IL, USA). Descriptive analysis was conducted for the distribution of characteristics of the subjects included. The Chi-squared test was applied to analyze the correlation of psychological distress with its associated risk factors.

\section{RESULTS}

The descriptive statistics of the subjects are shown in Table 1. Out of the total 1304 subjects, 463 were male and 841 were female. A total of $903(69.2 \%)$ respondents were from rural areas. A total of $1072(82.2 \%)$ participants reported practicing low-intensity exercises at least once a week (Table 1). In addition, a total of 1062(81.4\%) subjects showed psychological distress. Table 2 shows the association of psychological distress with the characteristics of the subjects. The results indicated that the education level of parents was significantly associated with psychological distress $(\mathrm{P}=0.001)$. Another interesting finding was that the students whose parents had middle-school or lower education were more likely to have psychological distress. A significant association of low-intensity exercise $(\mathrm{P}=0.034)$ and high-intensity exercise $(\mathrm{P}=0.003)$ with psychological distress was also found in this work. The results also identified that the frequency of exercise per week was associated with psychological distress. However, no significant association was detected between psychological distress and gender $(\mathrm{P}=0.162)$.

The distribution of the GHQ-12 score is shown in Figure 1.

\section{DISCUSSIONS}

The aim of the current study was to determine the psychological distress and its associated risk factors among university students. The study found that factors affecting psychological distress included education level of parents, low-intensity and high-intensity exercise. Our results also showed that more than half of the participants in our study presented psychological distress, and about $81.4 \%$ of 1304 scored 4 or above in the GHQ-12. The prevalence of psychological distress in studies from other countries was lower than 
our results. For example, about $55.5 \%$ in Singapore ${ }^{15}$ and $46.2 \%$ in Malaysia ${ }^{16}$ had psychological distress. The possible reason may be that the instruments used to measure psychological stress are different. Therefore, predictors of psychological stress among students need further investigation.

The finding of this study was that the prevalence of psychological distress among female students is higher than among males, though no statistical significance was identified. This is similar to that found by another study in Australian undergraduate students ${ }^{17}$. Whereas prospective symptom checklist -90 studies showed that Chinese male college students have more psychological distress ${ }^{18}$. This study indicates that we should pay attention to regional, cultural, and corresponding measurement tools when studying gender differences and psychological stress.

Another finding of the study was that the education level of parents was associated with the psychological stress of students, which was consistent with the results of an American study ${ }^{17}$. Although the education level of parents and income levels are often correlated, in a nationally representative longitudinal study of young adults in the US, the effect of parents' low education on adult depression symptoms was self-abasement, whereas the effect of parental low income was not inferior ${ }^{17}$. Students whose parents were less educated were prone to psychological stress ${ }^{19}$.

Additionally, an association of low-intensity and high-intensity exercise with psychological distress was found in the present study. Evidence from a previous study identified that high-intensity exercise was helpful for reducing psychological stress ${ }^{20}$. The useful submission from the findings was that self-reported exercise was credible for epidemiology studies.

Some limitations may also exist in the study. A shortcoming of the cross-sectional design was the failure to explore the cause-result relationship. Thus, further longitudinal studies are still required to examine the impact of low-intensity and high-intensity exercise

TABLE 1. SOCIODEMOGRAPHIC CHARACTERISTICS OF THE STUDY SAMPLE $(N=1304)$

\begin{tabular}{|c|c|c|c|}
\hline & Variable & Frequency & Percentage (\%) \\
\hline \multirow[t]{2}{*}{ Gender } & Male & 463 & 35.5 \\
\hline & Female & 841 & 64.5 \\
\hline \multirow[t]{5}{*}{ Grade } & One & 680 & 52.1 \\
\hline & Two & 373 & 28.6 \\
\hline & Three & 189 & 14.5 \\
\hline & Four & 61 & 4.7 \\
\hline & Graduate year 1 & 1 & 0.1 \\
\hline \multirow[t]{3}{*}{ Father education } & Primary school and low & 243 & 18. \\
\hline & Middle school & 895 & 68.6 \\
\hline & College and above & 165 & 12.7 \\
\hline \multirow[t]{3}{*}{ Mother education } & Primary school and low & 583 & 44.7 \\
\hline & Middle school & 619 & 47.5 \\
\hline & College and above & 100 & 7.7 \\
\hline \multirow[t]{2}{*}{ Location } & Rural area & 903 & 69.2 \\
\hline & Urban area & 400 & 30.7 \\
\hline \multirow[t]{4}{*}{ Income } & $<10000$ & 327 & 25.1 \\
\hline & $10000-30000$ & 426 & 32.7 \\
\hline & $30000-60000$ & 390 & 29.9 \\
\hline & $>60000$ & 156 & 12.0 \\
\hline \multirow[t]{4}{*}{ Low-intensity exercise } & never & 232 & 17.8 \\
\hline & 1 to 2 times per week & 718 & 55.1 \\
\hline & 3 to 4 times per week & 270 & 20.7 \\
\hline & More than 5 times per week & 84 & 6.4 \\
\hline \multirow[t]{4}{*}{ High-intensity exercise } & never & 522 & 40.0 \\
\hline & 1 to 2 times per week & 604 & 46.3 \\
\hline & 3 to 4 times per week & 127 & 9.7 \\
\hline & More than 5 times per week & 51 & 3.9 \\
\hline \multirow[t]{2}{*}{ GHQ dichotomy } & $<4$ & 242 & 18.6 \\
\hline & $\geq 4$ & 1062 & 81.4 \\
\hline
\end{tabular}


TABLE 2. PSYCHOLOGICAL DISTRESS AND ITS ASSOCIATED RISK FACTORS EVALUATION VALUE

\begin{tabular}{|c|c|c|c|c|c|}
\hline \multicolumn{2}{|l|}{ Variable } & \multirow{2}{*}{$\begin{array}{l}\mathrm{GHQ}<4 \\
70\end{array}$} & \multirow{2}{*}{\begin{tabular}{|l}
$\mathrm{GHQ} \geq 4$ \\
393
\end{tabular}} & \multirow{2}{*}{\begin{tabular}{|l|} 
Chi-Square value \\
$1.957^{\mathbf{a}}$ \\
\end{tabular}} & \multirow{2}{*}{\begin{tabular}{|l|} 
P-value \\
0.162
\end{tabular}} \\
\hline Gender & male & & & & \\
\hline & female & 104 & 737 & & \\
\hline \multirow[t]{5}{*}{ Grade } & One & 81 & 599 & 1.397 & 0.237 \\
\hline & Two & 61 & 312 & & \\
\hline & Three & 19 & 170 & & \\
\hline & Four & 13 & 48 & & \\
\hline & Graduate year 1 & 0 & 1 & & \\
\hline \multirow[t]{3}{*}{ Father education } & Primary school and below & 23 & 220 & 11.740 & 0.001 \\
\hline & Middle school & 115 & 780 & & \\
\hline & College and above & 36 & 129 & & \\
\hline \multirow[t]{3}{*}{ Mother education } & Primary school and below & 59 & 524 & 12.073 & 0.001 \\
\hline & Middle school & 94 & 525 & & \\
\hline & College and above & 21 & 79 & & \\
\hline \multirow[t]{2}{*}{ Location } & Rural area & 110 & 793 & $3.066^{\mathbf{a}}$ & 0.080 \\
\hline & Urban area & 63 & 337 & & \\
\hline \multirow[t]{4}{*}{ Income } & $<10000$ & 41 & 286 & 0.810 & 0.368 \\
\hline & $10000-30000$ & 57 & 369 & & \\
\hline & $30000-60000$ & 50 & 340 & & \\
\hline & $>60000$ & 26 & 130 & & \\
\hline \multirow[t]{4}{*}{ Low-intensity exercise } & never & 24 & 208 & 4.514 & 0.034 \\
\hline & 1 to 2 times per week & 95 & 623 & & \\
\hline & 3 to 4 times per week & 38 & 232 & & \\
\hline & More than 5 times per week & 17 & 67 & & \\
\hline \multirow[t]{4}{*}{ High-intensity exercise } & never & 53 & 469 & 8.666 & 0.003 \\
\hline & 1 to 2 times per week & 88 & 516 & & \\
\hline & 3 to 4 times per week & 24 & 103 & & \\
\hline & More than 5 times per week & 9 & 42 & & \\
\hline
\end{tabular}

Note: "a" represents Pearson Chi-Square

FIGURE 1. THE DISTRIBUTION OF GHQ-12 SCORES AMONG PARTICIPANTS

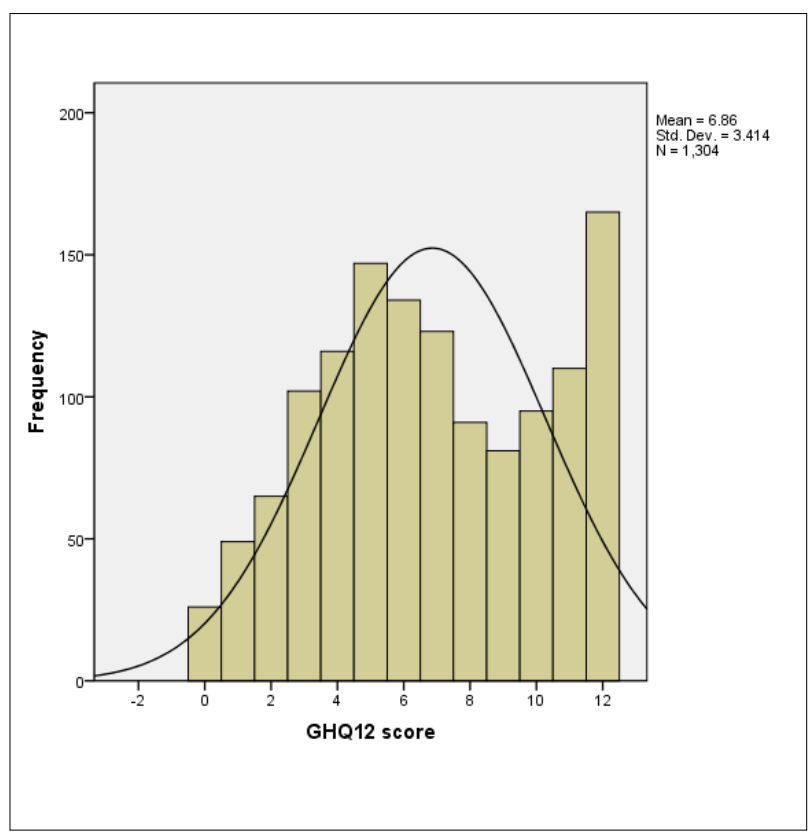

on psychological stress. Additionally, the population of this study is small and relatively uniform, future studies should recruit more students from different universities and regions.

\section{CONCLUSIONS}

The education level of parents, high-intensity, and low-intensity exercise were associated with psychological distress. Our results suggest that it is indispensable to raise awareness about psychological disorders and its associated risk factors among university students. Further studies should be developed.

\section{Acknowledgment}

This work was supported by the fund of development and output of teacher training curriculum for primary and middle school students in research and practical education, and the Research on the Construction of Curriculum System for the Cultivation of 
Outstanding Talents in Experience Industry (grant No. KH10000138), and scientific research projects of Anhui polytechnic university in 2019(grant No.xjky13201906).

\section{Disclosure}

The authors declare no conflict of interest.

\section{Author Contributions}

Conceived and designed the experiments; Baohong Xue and Dexun Zhao. Performed the experiments; Tingting li, Xu Zhang, Rui Wang, and Dexun Zhao. Analyzed the data; Lianping He. Wrote the paper; Tingting Li and Mingming Chen.

\section{RESUMO}

OBJETIVO: O estresse psicológico é um importante problema de saúde mental entre estudantes universitários. O objetivo deste estudo foi determinar o estresse psicológico e seus fatores de risco associados entre os estudantes na província de Anhui.

MÉTODOS: Um estudo transversal foi realizado entre uma amostra de 1.304 indivíduos. Nesse estudo, foi preenchido um questionário autoaplicável que consiste na demografia geral e no Questionário Geral de Saúde (GHQ-12). O problema psicológico foi avaliado utilizando o questionário GHQ de 12 itens. Uma divisão dicotômica de categoria foi imposta ao GHQ-12 para efeito de análise. Uma pontuação de quatro ou mais no GHQ-12 mostrava que um indivíduo tem problemas psicológicos. Os dados foram analisados pelo software SPSS 20.0.

RESULTADOS: Um total de 1.304 amostras foi analisado neste estudo. Os resultados indicaram que o nível de educação do pai e da mãe estava associado com estudantes em estresse psicológico $(P<0,001)$. Foi encontrada uma associação significativa entre o exercício de alta intensidade e o exercício de baixa intensidade com o estresse psicológico. No entanto, não foi identificada qualquer diferença significativa entre o gênero e o estresse psicológico $(P=0,173)$.

CONCLUSÃo: O nível de educação dos pais, exercícios de alta intensidade e exercícios de baixa intensidade foram associados com estresse psicológico. Nossos resultados sugerem que é indispensável aumentar a sensibilização para as perturbações psicológicas e para os fatores de risco associados aos estudantes universitários. São necessários mais estudos para desenvolver intervenções adequadas para grupos de alto risco.

PALAVRAS-CHAVE: Estresse psicológico. Fatores de risco. Estudantes. Universidades.

\section{REFERENCES}

1. Baxter AJ, Scott KM, Vos T, Whiteford HA. Global prevalence of anxiety disorders: a systematic review and meta-regression. Psychol Med. 2013;43(5):897-910.

2. Whiteford HA, Degenhardt L, Rehm J, Baxter AJ, Ferrari AJ, Erskine HE, et al. Global burden of disease attributable to mental and substance use disorders: findings from the Global Burden of Disease Study 2010. Lancet. 2013;382(9904):1575-86.

3. Lincoln KD, Taylor RJ, Watkins DC, Chatters LM. Correlates of psychological distress and major depressive disorder among African American men. Res Soc Work Pract. 2011;21(3):278-88.

4. Arias-de la Torre |, Molina AJ, Fernández-Villa T, Artazcoz L, Martín V. Mental health, family roles and employment status inside and outside the household in Spain. Gac Sanit. 2019;33(3):235-41.

5. Arias-de la Torre J, Fernández-Villa T, Molina AJ, Amezcua-Prieto C, Mateos $\mathrm{R}$, Cancela $\mid \mathrm{M}$, et al. Psychological distress, family support and employment status in first-year university students in Spain. Int J Environ Res Public Health. 2019;16(7). doi: 10.3390/ijerph16071209.

6. American College Health Association. American College Health Association-National College Health Assessment Spring 2008 Reference Group Data Report (abridged): the American College Health Association. J Am Coll Health. 2009;57(5):477-88.

7. Ip V, Chan F, Chan JY, Lee JK, Sung C, H Wilson E. Factors influencing Chinese college students' preferences for mental health professionals. Ment Health. 2016;25(2):142-7.

8. Wang PS, Angermeyer M, Borges G, Bruffaerts R, Tat Chiu W, De Girolamo $G$, et al. Delay and failure in treatment seeking after first onset of mental disorders in the World Health Organization's World Mental Health Survey Initiative. World Psychiatry. 2007;6(3):177-85.

9. Tang F, Byrne M, Qin P. Psychological distress and risk for suicidal behavior among university students in contemporary China. J Affect Disord. 2018;228:101-8.
10. Bacchi S, Licinio J. Resilience and psychological distress in psychology and medical students. Acad Psychiatry. 2017;41(2):185-8.

11. Bhat US, Amaresha AC, Kodancha P, John S, Kumar S, Aiman A, et al. Psychological distress among college students of coastal district of Karnataka: a community-based cross-sectional survey. Asian J Psychiatr. 2018;38:20-4.

12. Zhang M, Zhang J, Zhang F, Zhang L, Feng D. Prevalence of psychological distress and the effects of resilience and perceived social support among Chinese college students: does gender make a difference? Psychiatry Res. 2018;267:409-13.

13. Liang $Y$, Wang $L$, Yin $X$. The factor structure of the 12-item general health questionnaire (GHQ-12) in young Chinese civil servants. Health Qual Life Outcomes. 2016;14(1):136.

14. Lindkvist M, Feldman I. Assessing outcomes for cost-utility analysis in mental health interventions: mapping mental health specific outcome measure GHQ-12 onto EQ-5D-3L. Health Qual Life Outcomes. 2016;14(1):134.

15. Ko SM, Kua EH, Fones CS. Stress and the undergraduates. Singapore Med J. 1999;40(10):627-30.

16. Zaid ZA, Chan SC, Ho J). Emotional disorders among medical students in a Malaysian private medical school. Singapore Med J. 2007;48(10):895-9.

17. Eisenberg D, Gollust SE, Golberstein E, Hefner JL. Prevalence and correlates of depression, anxiety, and suicidality among university students. Am J Orthopsychiatry. 2007;77(4):534-42.

18. Liu F, Zhou N, Cao H, Fang X, Deng L, Chen W, et al. Chinese college freshmen's mental health problems and their subsequent help-seeking behaviors: a cohort design (2005-2011). PLoS One. 2017;12(10):e0185531.

19. Swartz JR, Knodt AR, Radtke SR, Hariri AR. Post-secondary maternal education buffers against neural risk for psychological vulnerability to future life stress. Neuropsychologia. 2018;109:134-9.

20. McAllister MJ, Basham SA, Waldman HS, Smith JW, Mettler JA, Butawan $M B$, et al. Effects of psychological stress during exercise on markers of oxidative stress in young healthy, trained men. Physiol Behav. 2019;198:90-5. 